\title{
LYSIS OF PHOTOGRAPHIC EMULSIONS BY MAMMALIAN AND CHICKEN SPERMATOZOA
}

\author{
G. J. ALLEN, M. W. H. BISHOP AND T. E. THOMPSON \\ Departments of Animal Husbandry and Zoology, \\ University of Bristol, Langford, Bristol BS18 $7 D U$
}

(Received 23rd August 1973)

Gaddum \& Blandau (1970) studied the proteolytic activity of individual mammalian spermatozoa by directly observing the dissolution of pure gelatin membranes which had been blackened by the inclusion of India ink and fixed with glutaraldehyde. Their observations showed that lytic enzymes were released from the acrosomal region of the sperm head, but not from other parts of the cell.

Gaddum \& Blandau's technique has two important practical disadvantages. Firstly, the 'home-made' gelatin membranes used are tedious to prepare and variable in thickness, and, secondly, the incorporation of India ink obscures the images of the spermatozoa. To counter the second of these disadvantages, Benítez-Bribiesca \& Velázques-Meza (1972) used Ponceau stain instead of India ink, and Gaddum-Rosse \& Blandau (1972) used clear unstained membranes. To eliminate both kinds of disadvantage, we have explored the use of commercial photographic emulsions as a source of gelatin substrate, a technique which has been used for many years to study the enzymatic activity of tissue slices (Gordon, Levin \& Whitehead, 1952; Adams, Fernand \& Schneiden, 1958; Adams \& Tuquan, 1961; Kirchner, 1972).

Our first observations were made with blackened photographic plates, such as Kodak P300. After exposure to light, these plates were processed in the usual way and, after washing, were fixed in $0.05 \%$ glutaraldehyde in veronal-acetate buffer ( $\mathrm{pH} \mathrm{8.2)} \mathrm{for} 2 \mathrm{~min}$ and then rinsed in buffer and distilled water. Washed spermatozoa, suspended in a mixture of Hanks' BSS medium (B.D.H.) and veronal acetate buffer, were spread onto these plates and incubated at $37^{\circ} \mathrm{C}$ in a humid atmosphere. The results obtained were essentially the same as those described by Gaddum \& Blandau (1970) but with less variability. The areas of depolymerization were very clear, but details of the reacting spermatozoa remained obscured by the blackened emulsions. Very much better images were then obtained by using colour film, such as Kodachrome II, exposed and developed to produce a light red or light blue background. These films are, however, relatively expensive and celluloid film is much less convenient to use than glass plate, which can be cut to the size of a microscope slide and remains solid and flat without additional mounting. We therefore returned to the use of black and white photographic plates but fixed them with Kodafix without exposure either to light or chemical development. These plates are easy to prepare and have given excellent results. Their gelatin coats are transparent, 
with a faint brown colour, and are uniform in thickness. Details of sperm structure and associated areas of depolymerized emulsion can be clearly seen, especially by phase-contrast microscopy (see Plate 1).

With these plates, observations have been made on the lytic activities of spermatozoa from the following species: rat, mouse, guinea-pig, ram, bull, boar, man and domestic chicken. In each case, the spermatozoa depolymerized an area of gelatin film around the sperm head in the manner described by Gaddum \& Blandau (1970) and Gaddum-Rosse \& Blandau (1972). The first sign of this reaction was a lightening of the colour of the gelatin adjacent to the equatorial segment of the sperm head. This area then quickly spread around the lateral edges of the acrosome (at first producing an asymmetrical area around the convex margin of the heads of the rat and mouse spermatozoa) and eventually increased in size to envelop the entire head and the anterior section of the tail in a white, roughly circular area of depolymerization. The times at

Table 1. Dissolution of photographic emulsion* by the spermatozoa of a variety of species at $\mathrm{pH} 8 \cdot 2$

\begin{tabular}{|c|c|c|c|c|c|c|}
\hline Species & $\begin{array}{l}\text { Source of } \\
\text { sample }\end{array}$ & $\begin{array}{c}\text { No. of } \\
\text { samples }\end{array}$ & $\begin{array}{c}\text { Start of } \\
\text { reaction } \\
(h r)\end{array}$ & $\begin{array}{c}\text { End of } \\
\text { reaction } \\
\text { (days) }\end{array}$ & $\begin{array}{c}\text { Mean area of } \\
\text { reaction circle } \\
( \pm S . E .) \text { after } 24 \mathrm{hr} \\
\left(\mu \mathrm{m}^{2}\right)\end{array}$ & $\begin{array}{l}\text { Approx. mean final } \\
\text { area of reaction circle } \\
\left(\mu \mathrm{m}^{2}\right)\end{array}$ \\
\hline $\begin{array}{l}\text { Rat } \\
\text { Mouse } \\
\text { Guinea-pig } \\
\text { Ram } \\
\text { Bull } \\
\text { Boar } \\
\text { Man } \\
\text { Chicken }\end{array}$ & $\begin{array}{l}\text { Ductus deferens } \\
\text { Ductus deferens } \\
\text { Ductus deferens } \\
\text { Cauda epididymidis } \\
\text { Ejaculated } \\
\text { Ductus deferens } \\
\text { Ejaculated } \\
\text { Ejaculated }\end{array}$ & $\begin{array}{l}3 \\
3 \\
3 \\
3 \\
1 \\
8 \\
6 \\
6 \\
3\end{array}$ & $\begin{array}{l}21 \\
4.5 \\
2 \text { to } 2 \cdot 5 \\
1.5 \\
0.5 \\
2.0 \\
0.5 \\
1.75\end{array}$ & $\begin{array}{l}4 \\
4 \\
2 \\
2 \\
2 \cdot 5 \\
2 \\
3 \\
2\end{array}$ & $\begin{array}{r}28 \cdot 5 \pm 2 \cdot 1 \\
61 \cdot 0 \pm 2 \cdot 1 \\
3018 \cdot 0 \pm 93 \cdot 4 \\
1821 \cdot 0 \pm 144 \cdot 1 \\
741 \cdot 0 \pm 28 \cdot 4 \\
1337 \cdot 0 \pm 107 \cdot 5 \\
695 \cdot 0 \pm 21 \cdot 1\end{array}$ & $\begin{array}{r}- \\
200 \\
4100 \\
5000 \\
5000 \\
2000 \\
3000 \\
1200\end{array}$ \\
\hline
\end{tabular}

* Ilford Selochrome Plate.

which this process started and finished and the final sizes of the depolymerized areas varied significantly between the spermatozoa of different species. Depolymerization was first evident after about $30 \mathrm{~min}$ with human and bull spermatozoa, but was delayed for about $21 \mathrm{hr}$ with rat spermatozoa (see Table 1). The reaction was complete in 2 days with guinea-pig and chicken spermatozoa, and in $2 \frac{1}{2}$ days with bull spermatozoa, but required about 4 days with the spermatozoa of the rat and mouse (see Table 1). The largest areas of depolymerization were produced by bull and ram spermatozoa, and the smallest by mouse spermatozoa.

For reasons that are not understood, the reaction circles varied somewhat in size (and in time of onset) along the length of the smear, as was also observed

\section{EXPLANATION OF PLATE 1}

Depolymerization of photographic emulsions (Ilford Selochrome Plate) by mammalian and chicken spermatozoa.

Figs 1 and 2. Boar spermatozoa after 21 and $23 \mathrm{hr} . \times 740$.

Frgs 3 and 4. Bull spermatozoa after $\frac{1}{2} \mathrm{hr}(\times 500)$ and $48 \mathrm{hr} . \times 380$.

Figs 5 and 6 . Ram spermatozoa after $1 \frac{1}{2}$ and $24 \mathrm{hr} . \times 450$.

Figs 7 and 8. Mouse spermatozoa after 10 and $72 \mathrm{hr} . \times 630$.

FIGs 9 and 10. Guinea-pig spermatozoa after 4 and $40 \mathrm{hr} . \times 475$.

FIGs 11 and 12. Chicken spermatozoa after 4 and $23 \mathrm{hr} \times 340$. 
PLATE: 1
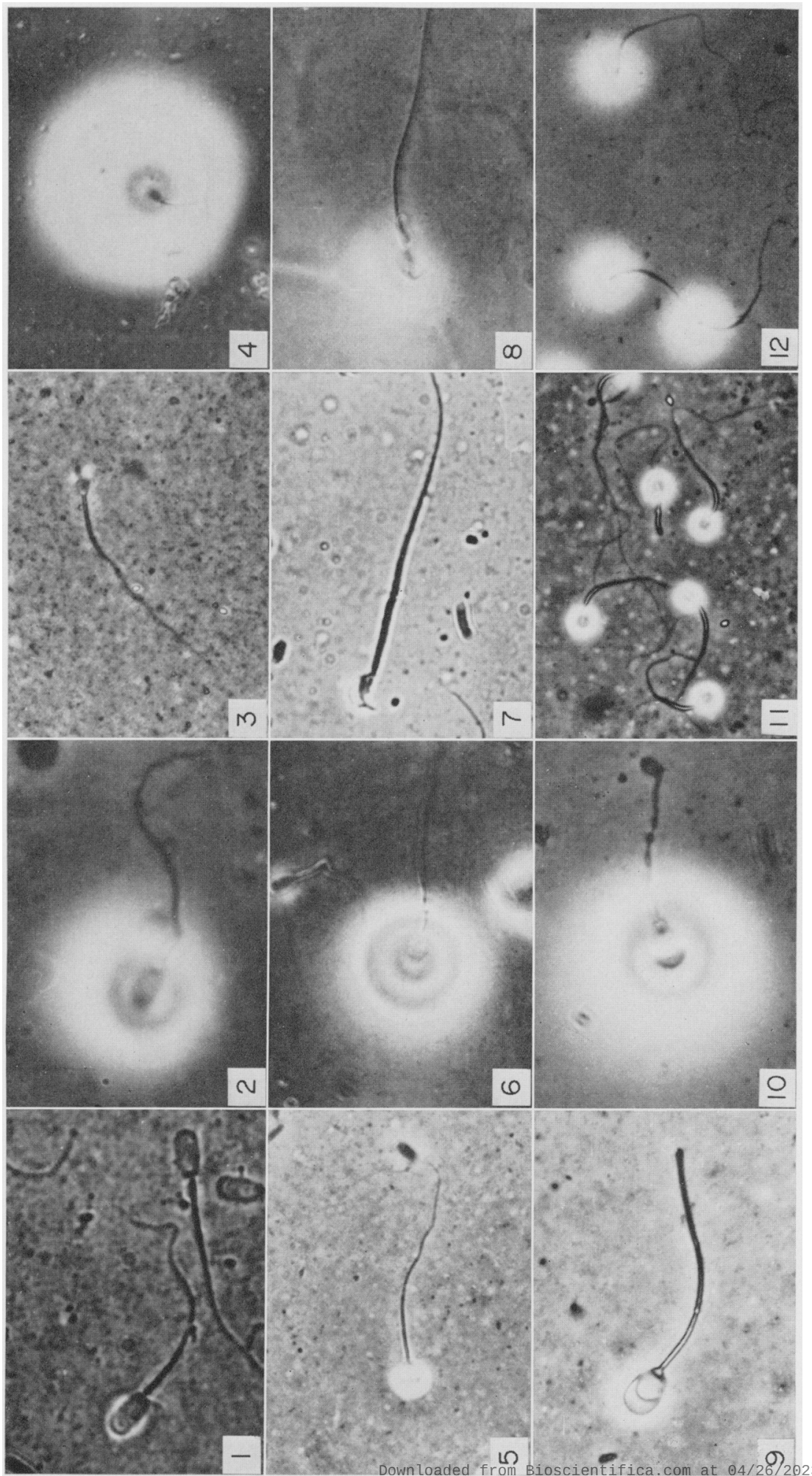
by Gaddum-Rosse \& Blandau (1972). Because of this, the observations recorded in Table 1, which were made with an image-splitting eyepiece, were restricted to the area extending from 1.0 to $1.5 \mathrm{~cm}$ from the origin of the smear. There was little variation across the smear. Estimates of the endpoint of the reactions tend to be subjective and our most reliable data were those made after $24 \mathrm{hr}$. No similar measurements have been provided by other workers.

Using this technique, we observed that the optimum $\mathrm{pH}$ appeared to vary slightly between different species and that the size of the reaction circle was significantly reduced $(P<0.001)$ by seminal plasma and by $0.1 \mathrm{~m}$-Versine (EDTA). Depolymerization of the emulsion was abolished by treating the spermatozoa with 5 or $10 \%$ formalin, commercial detergents such as Triton $\mathrm{X}-100$, Hyamine 2389 and Alconox, 0.1 M-sodium hydroxide, Soybean Trypsin inhibitor (Type 1-S, Sigma), N- $\alpha$-p-tosyl-L-lysine chloromethyl ketone (TLCK, Sigma) or saturated cupric sulphate solutions, but not by storage for up to 2 months in a commercial deep freeze or by repeated freezing and thawing. The lytic activity of spermatozoa from the testis and caput, corpus and cauda areas of boar and ram epididymides was also studied. There was a significant difference $(P<0.001)$ between the different regions, the activity increasing from the testis to the cauda epididymidis. Cytoplasmic droplets displayed no proteolytic activity, although they are known to contain lysosomal enzymes (Dingle \& Dott, 1968).

It seems highly probable that the enzyme responsible for this depolymerization is the same as the 'zona lysin' postulated by Austin \& Bishop (1958) and the 'trypsin-like enzyme' of the mammalian spermatozoa described by Stambaugh \& Buckley (1968, 1969, 1970). According to Adams \& Tuquan (1961), 1 pg trypsin digests a $30-\mu \mathrm{m}$ diameter hole in photographic emulsions. It is notable that the amount of enzyme released appears to bear little relationship to the size of the acrosome, which causes us to doubt whether the acrosome is the source of the enzyme, as Gaddum-Rosse \& Blandau (1972) and Stambaugh \& Buckley (1970) suppose. Austin \& Bishop (1958) have suggested that zona lysin comes from the perforatorium which lies beneath the acrosome. The release of the enzyme in the present experiments evidently results from postmortem degeneration changes in the spermatozoa.

\section{REFERENGES}

Adams, C. W. M., Fernand, V. S. W. \& Schnemen, H. (1958) Histochemistry of a condition resembling kwashiorkor produced in rodents by a low protein-high carbohydrate diet (Cassava). Br. F. exp. Path. 39, 393.

Adams, G. W. M. \& TuQuan, N. A. (1961) The histochemical demonstration of proteases by a gelatinsilver film substrate. F. Histochem. Cytochem. 9, 469.

Austis, C. R. \& Bishop, M. W. H. (1958) Role of the rodent acrosome and perforatorium in fertilization, Proc. R. Soc. B, 149, 241.

Benítez-Bribiesca, L. \& Velázques-Meza, S. (1972) Cytochemical demonstration of proteolytic activity of human and rat spermatozoa. F. Reprod. Fert. 29, 419.

Dingle, J. T. \& DotT, H. M. (1968) Lysosomal enzymes in bull and ram semen. Biochem. 7. 111, 35.

Gaddum, P. \& Blandau, R. J. (1970) Proteolytic reaction of mammalian spermatozoa on gelatin membranes. Science, $\mathcal{N}$. Y. 170, 749.

Gaddum-Rosse, P. \& Blandau, R. J. (1972) Comparative studies on the proteolysis of fixed gelatin membranes by mammalian sperm acrosomes. Am. F. Anat. 134, 133.

Gordon, I., Levin, B. \& WhiteheAd, T. P. (1952) Estimation of trypsin in duodenal juice. Br. med. F. i, 463. 
Kirchner, C. (1972) Uterine protease activities and lysis of the blastocyst covering in the rabbit. J. Embryol. exp. Morph. 26, 177.

Stambaugh, R. \& Buckley, J. (1968) Zona pellucida dissolution enzymes of the rabbit sperm head. Science, N.Y. 161, 585 .

StAMBAUgh, R. \& BUCKLEY, J. (1969) Identification and subcellular localization of the enzymes affecting penetration of the zona pellucida by rabbit spermatozoa. 7 . Reprod. Fert. 19, 423.

Stambaugh, R. \& Buckley, J. (1970) Comparative studies of the acrosomal enzymes of rabbit, rhesus monkey and human spermatozoa. Biol. Reprod. 3, 275. 